\title{
DEVELOPMENT OF ORGANIC FARMERS' COOPERATIVES: THE USA, THE EU, AND UKRAINE
}

\author{
Roman Bezus', Ihor Bilotkach ${ }^{2}$ \\ Dnipro State Agrarian and Economic University, Ukraine
}

\begin{abstract}
The purpose of the paper is to formulate and to present recommendations on the development of organic cooperatives in Ukraine based on the experience of successful cooperatives from the US and the EU. An overview of their formation and financing, implementation of projects in organic cooperatives in different countries provide a powerful basis to formulate recommendations on how to avoid errors and to choose the best solutions for organic cooperatives in Ukraine. Methodology. The research is based on a comparison of data, describing the creation and development of organic farmers' cooperatives in the US and such EU countries as France, Austria, and Ireland. Also, the actual characteristics of organic cooperatives in Ukraine and marketing cooperatives will be given. According to the obtained comparisons, recommendations on the further development of Ukrainian organic farmers' cooperatives will be presented. Results. As a result of research, a special set of recommendations was formed. Notably, the following important conditions of successful activity of organic farmers' cooperatives were indicated, as loyalty to the idea of producing organic products; optimal time planning for the project implementation; the importance of financial literacy training; the need to consider the views of all members of the cooperative; attracting scientists, managers and marketers to coop's activities and so on. Practical implications. The considered array of practices of organic farmers' cooperatives in the US and the EU helped to form a special set of recommendations for Ukrainian organic farmers and revealed that ideological factors have a powerful influence on the success of organic cooperatives. In particular, the loyalty to the idea of producing organic products and listening to the opinion of every cooperative's member helps to overcome the crisis almost as well as additional funding. Value/originality. The presented recommendations provide an opportunity to understand the ways of developing the organic farmers' cooperative, help to avoid risks optimally and support organic farmers' cooperative movement in Ukraine.
\end{abstract}

Key words: farmer cooperatives, organic agriculture, marketing cooperatives, organic farmer cooperatives, US-EU cooperatives.

\section{JEL Classification: Q13, Q50}

\section{Introduction}

Organic sector of agrarian business continues to expand worldwide. According to the study (Lernoud, Willer, 2018), in 2016 the world's organic agricultural area increased by 7.5 million hectares, or by $15 \%$ compared to the previous year. The number of organic producers has grown to 2.7 million, and the global market of organic production has grown to $\$ 90$ billion. Organic food production and consumption have increased also in the USA and the EU. The countries with the largest markets of organic products are the United States ( $\$ 38.9$ billion), Germany ( $\$ 9.7$ billion), and France ( $\$ 6.7$ billion).

In 2018, Ukrainian consumers also more often choose organic products than in previous years. In response to such interest, Ukrainian farmers expanded the range of products produced according to organic standards. Today the "organic basket" of Ukraine consists of vegetables, fruits, juices, jams, meat, dairy, pasta, bread, herbal teas etc.

In 2017, Ukrainian organic market amounted to 21 million euros (Trofimtseva, Prokopchuk, 2018). At the same time, market conditions push Ukrainian farmers, including those who work in organic farming, to start cooperatives. The most of Ukrainian farmers are not able to purchase valuable organic fertilizers or equipment that is suitable for organic farming.

The active organic farmers' cooperative is a new phenomenon for Ukraine, and in Europe and the USA, there is already an experience of such agrarian associations. Therefore, it is important to study the state of development of organic farmers' cooperatives in the

Corresponding author:

${ }^{1}$ Department of Marketing, Dnipro State Agrarian and Economic University.

E-mail: bezusrm@gmail.com

${ }^{2}$ Department of Marketing, Dnipro State Agrarian and Economic University.

E-mail: bilotkach@ukr.net 
USA and the EU in order to develop recommendations for such cooperatives in Ukraine.

The purpose of the paper is to formulate and to present recommendations on the development of organic cooperatives in Ukraine based on the experience of successful cooperatives from the US and the EU. An overview of their formation and financing, implementation of projects in organic cooperatives in different countries provide a powerful basis to formulate recommendations on how to avoid errors and to choose the best solutions for organic cooperatives in Ukraine.

To achieve the purpose of the paper, the data describing the creation and development of organic farmers' and marketing cooperatives in the US and the EU will be gathered. Also, the actual characteristics of organic cooperatives in Ukraine will be given.

\section{US organic farmers' cooperatives}

US organic market shows strong growth in recent years. Now it is the largest in the world and is 38.9 billion dollars, which is $\$ 3.1$ billion more than in the previous year. And $5.3 \%$ of all products purchased in the US are produced according to organic standards (Lernoud, Willer, 2018). The dynamics of the size of organic agricultural land, the number of producers and the market of such products in the US during 20142016 can be seen in Table 1 .

\section{Table 1}

US organic agricultural land, number of producers, and market of organic products in 2014-2016

\begin{tabular}{|l|c|c|c|c|}
\hline \multirow{2}{*}{ Indicator } & \multicolumn{3}{|c|}{ Year } & $\begin{array}{c}\text { 3 yrs growth, } \\
(\%)\end{array}$ \\
\cline { 2 - 5 } & 2014 & 2015 & 2016 & +30 \\
\hline $\begin{array}{l}\text { Agricultural land, } \\
\text { thousand ha }\end{array}$ & 1554 & 2029 & 2031 & +10 \\
\hline Producers & 12880 & 14871 & 14217 & +44 \\
\hline Market, \$ billion & 27,06 & 35,8 & 38,9 & + \\
\hline
\end{tabular}

Source: (Haumann B. 2016, 2017, 2018)

As the table shows, in three years, US organic agricultural land increased by $30 \%$, while the number of organic producers increased by $10 \%$. The local organic market increased by $44 \%$ during the research period. That is, the development of the organic sector of agribusiness in the United States is gradually continuing, bringing benefits both to the producers of such production and to its consumers.

The history of US cooperation has deep roots. The first US cooperative is an insurance cooperative founded by Benjamin Franklin in 1752, which is still operating (UW Center for Cooperatives, 2010).

In 2016, there were 30000 cooperatives in the United States, uniting 350 million people. 3000 of them are farmers' cooperatives, which provide more than 25 thousand jobs with a total salary of over $\$ 8$ billion.
Almost all of the US farmers' cooperatives produce few types of organic products (UW Center for Cooperatives, 2017).

It is interesting that the demand for organic food after World War II contributed to the development of agricultural cooperatives in the United States. In the 60s and 70s, a lot of such cooperatives were formed, most of which collapsed, but survivors now have a strong influence on the local and global organic markets (UW Center for Cooperatives, 2010).

According to the Coop Directory Service Listing, currently, there are 489 farmers' cooperatives in the United States, the main profile of which is producing organic agricultural products. As an example of successful organic farmers' cooperative can be named "Organic Valley" and "Deep Root Organic Cooperative" (Coopdirectory, 2017).

Assessing the effectiveness of US cooperatives in 2016, it turned out that agricultural cooperatives earned 56\% of the cooperatives' profits. The share of cooperatives' profits of other sectors of the economy can be seen in Fig. 1.

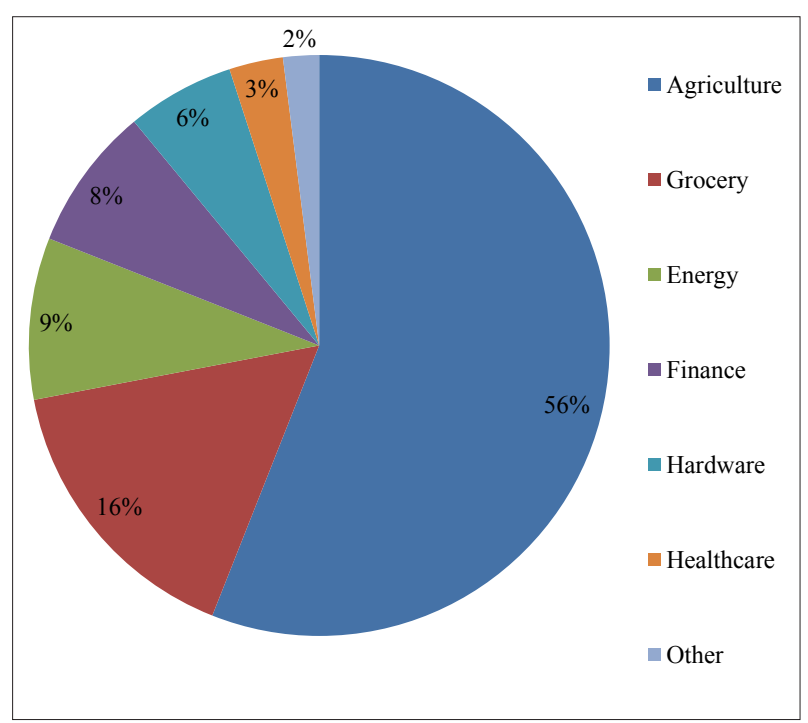

Fig. 1. Shares of coops' revenue by sector

Source: (Hadfield, 2017)

Economic activity of the US agricultural cooperatives is constantly examined by USDA. The profit's dynamics of five most successful conventional cooperatives and one organic agricultural cooperative during 2015-2016 can be seen in Table 2 .

As can be seen from the table, four out of five most successful US farmers' cooperatives in 2016 received a slightly lower profit than a year ago. This decrease can be explained by the expansion of cooperative's products market and increasing competition. During the study period the most successful organic cooperative climbed 4 positions to 22 seats and unlike conventional cooperatives could increase revenue by $4 \%$. 
Table 2

US coops in 2015-2016

\begin{tabular}{|c|c|c|c|c|c|}
\hline \multirow{2}{*}{$\begin{array}{c}\text { Rank in } \\
2016\end{array}$} & \multirow{2}{*}{ Name } & \multirow{2}{*}{ Type of products } & \multicolumn{2}{|c|}{ Revenue in $\$$ billions } & \multirow{2}{*}{$\begin{array}{l}1 \text { y growth, } \\
(\%)\end{array}$} \\
\hline & & & 2015 & 2016 & \\
\hline 1 & CHS Inc. Saint Paul & Mixed (Energy, Supply, Grain, Food) & 34,69 & 30,53 & -12 \\
\hline 2 & Dairy Farmers of America Kansas City & Dairy & 13,90 & 13,62 & -2 \\
\hline 3 & Land O’Lakes, Inc. Saint Paul & Mixed (Supply, Dairy, Food) & 13,07 & 13,27 & +2 \\
\hline 4 & GROWMARK, Inc. Bloomington & Dairy & 8,74 & 7,07 & -19 \\
\hline 5 & Ag Processing Inc. Omaha & Dairy & 4,45 & 3,41 & -23 \\
\hline- & - & - & - & - & - \\
\hline 22 & $\begin{array}{l}\text { Cooperative Regions of Organic Producer } \\
\text { Pools (CROPP)/Organic Valley }\end{array}$ & Dairy & 1,01 & 1,05 & +4 \\
\hline
\end{tabular}

Source: (USDA, 2016)

The way of the largest and most successful organic cooperative "Organic Valley" began in 1988, when the United States had a crisis of agrarian sector and small farmers were not able to continue production. There was no special aid for organic farmers because all the funds went to industrial agriculture.

The farm owners of thelocal community, where now the Organic Valley is, did not want to switch to agribusiness with chemical fertilizers, so it was decided to unite the community and to seek solutions together. The meeting decided to save the community's environment and to continue producing organic products. The first coop's products party that was able to compete with agrarian holdings' one was a party of organic vegetables, and a year later the cooperative began to sell its own branded organic milk. Consumers saw the difference between Organic Valley's and other local producers' products and have opted for cooperative's organic products. After other farmers saw a strong demand for such products, they chose to join the cooperative. Thus, for the members of this cooperative, the crisis has passed and they began to receive first profits. Today the cooperative brings together more than 2000 farmers from the United States, which produce organic vegetables, milk, and dairy products, soybeans, and chicken eggs under their own brand name (organicvalley.coop, 2018).

The key elements of this success of the farmers' cooperative are:

- the loyalty to the idea of production without adding chemicals, despite market pressure and other circumstances;

- using simple practices and ingredients;

- enabling farm animals to be just animals: all processes must be as natural as possible;

- don't be tempted with the idea of expansion to industrial scale;

- electing only the local successful farmer as the head of the cooperative.

These ideas are relevant for Ukrainian organic farmers wishing to join a cooperative to grow their business (organicvalley.coop, 2018).

Deep Root Organic Cooperative, the second-largest organic cooperative, has not entered the first hundred
United States cooperatives, which annually explores the USDA as a previous one but also has noticeable results.

It was created in 1985, during the same crisis period for organic producers in the United States. It consisted of grain producers and faced the same problems as the previous cooperative. But there was the difference: the demand for organic crops was higher than for organic vegetables and milk. The following measures helped to pass the crisis for the newly created farmers' cooperative: - to gather in cooperative only the true ideologues of organic grain production;

- to employ a manager and a marketer who will promote products and distribute information about the cooperative;

- to conduct trainings for updating knowledge about new organic technologies in grain production (deeprootorganic.coop, 2018).

The US farmers' experience revealed an important element of the success of organic cooperatives in critical periods: to be loyal to the idea of producing organic products and to use marketing instruments that may eventually lead to the significant success.

\section{EU organic farmers' cooperatives}

The EU is a powerful player in the world of organic agribusiness almost as big as the United States. The EU's organic market in 2016 was the second largest in the world after the United States' and accounted for $37 \%$ of the world organic market that year. Its volume amounted to 30.7 billion euros, which is $11 \%$ more than in the previous year (Willer, Schaak, Lernoud, 2018).

The countries with the largest organic markets in the EU are Germany, France, and Italy. Data on the dynamics of organic agricultural land, the number of producers and market volume in the EU during 20142016 is summarized in Table 3.

For three years, the organic agricultural land of the EU has grown moderately - by $18 \%$, and organic agricultural producers' number has grown by $14.5 \%$. However, the market for such products expanded by $28.5 \%$ over the same period. It can be concluded that the EU organic market is growing gradually, expanding 
Table 3

EU organic agricultural land, number of producers, and market of organic products in 2014-2016

\begin{tabular}{|l|c|c|c|c|}
\hline \multirow{2}{*}{ Indicator } & 2014 & 2015 & 2016 & $\begin{array}{c}3 \text { Yrowth, } \\
\text { (\%) }\end{array}$ \\
\cline { 2 - 5 } & 10,25 & 11,19 & 12,1 & +18 \\
\hline $\begin{array}{l}\text { Agricultural land, } \\
\text { thousand ha }\end{array}$ & 257525 & 269453 & 295123 & $+14,5$ \\
\hline Producers & 23,9 & 27,1 & 30,7 & $+28,5$ \\
\hline $\begin{array}{l}\text { Market, billion } \\
\text { Euro }\end{array}$ &
\end{tabular}

Source: (Willer, Schaak, 2016; Willer, Schaak, Lernoud, 2017, 2018)

the offer of certified organic products and attracting more consumers each year.

In the EU, organic farmers' cooperative develops through the Rural Development Program for 20142020, which is held under the Common Agricultural Policy (CAP). The main objectives of this program are:

- fostering knowledge transfer and innovation;

- preserving and enhancing ecosystems;

- promoting resource efficiency and acting on climate;

- social inclusion and the economic development of rural economies (European Commission, 2013).

This program has a special Measure 16 "Cooperation" that supports the idea of combining agrarian producers and other agribusiness members to create innovative products or technologies. Measure 16 "Cooperation" in addition to organic production supports the development of agro-tourism, local farmers' markets, farm diversification, increasing the total biomass for food and green energy.

In addition to the main Measure 16 "Cooperation" of the Rural Development Program for 2014-2020, there are other Measures that support the development of advisory services, research, other knowledge sharing activities, investment projects, in particular, for cooperatives with an organic component (European Commission, 2013). Such support greatly facilitates the spread of cooperation ideas and the improvement of organic production methods in Europe.

The experience of each cooperative is unique; therefore, it is advisable for Ukrainian farmers to consider examples of the development of organic cooperatives from different European countries with similar climatic or market conditions as in Ukraine.

A striking example of the powerful development of organic cooperative's movement in the EU is the signing by all agricultural cooperatives of France a declaration on the support of the organic movement in 2017. Signing this document means that all agricultural cooperatives pledged to support the development of organic production.

At the beginning of 2017, there were 11545 agricultural cooperatives in France with an income of 86 billion euros. 550 cooperatives bring together farmers specializing in organic production. And in
2016, the French market of organic products grew by $20 \%$ compared to the 2015 year. Organic agricultural cooperatives in this country produce almost $90 \%$ of organic pork, $78 \%$ of organic grain, $36 \%$ of organic milk, and $25 \%$ of organic vegetables and fruits (Voinea, 2017; La cooperation agricole, 2017).

A unique form of farming cooperation is uniting the efforts to meet demand in a particular product. In France, these kinds of products are legendary cheese and wine. The raw material for them should be of invariably high quality, so some French farmers and processors are united into cooperatives engaged in securing the production of only one specialized product that has been stable in high demand for centuries (Erinyak, 2013).

Let's consider the project of French organic cooperative, which specializes in services for producers of organic grains that also are actively cultivated in Ukraine.

Organic grain cooperative "Coopérative régionale d'agriculture biologique" was founded in France in 1998. At that time, France, Germany, and the Netherlands began to lead in consumption and production of organic products in the EU. The cooperative worked successfully and in 2011 the members of the cooperative had already grown 22 types of organic grains and had the opportunity to store more than $80 \%$ of the members' products from the regions of Poitou-Charentes, Limousin, Pays-deLoire, and Aquitaine.

Such significant volumes of organic grains required appropriate storage and processing volumes that comply with EU and US organic standards (Leriox, 2015).

The funds for the construction of new storage facilities and reconstruction of old ones were obtained from 18 producers and 3 processors of organic products. Thanks to the members of the cooperative, $65 \%$ of the required investment amount was collected, while the remaining $35 \%$ was provided by the local authorities and the Ministry of Agriculture of France.

As a result of the project implementation, the storage, ventilation, and sorting facility for 5000 tons of organic grains was constructed. When using new warehouses, all farmers and processors noted the improvement of the stored grains' quality.

As was pointed by J. Leriox, it is needed to understand the important aspects of making such a valuable cooperative project:

- it takes a lot of time to reach agreements with all project participants, not just with the majority;

- the cooperative board must openly meet all the ideas and discuss them in detail;

- it is necessary to plan the project taking into account future modernization and attraction of innovations (Leriox, 2015).

In addition to organic grain growing, greenhouse crops growing is also popular in Ukraine. This type of organic agribusiness is possible in those areas where 
open land can't be certified according to organic standards. However, such production usually needs a lot of energy for lighting and heating.

Organic greenhouse lettuce producers in Austria faced the similar complex of issues. Due to the harsh climatic conditions in this country, only a few local organic green crops are grown and a lot of them are imported. But the demand of local residents concentrated on local organic greens. Therefore, there is a necessity of increasing the volume of local organic greenhouse green crops without adding pollution to the environment.

To achieve this goal, the "Winter Crop" project was created, the essence of which was the innovative and technological support of farmers growing organic vegetable and green crops all year round. This project was implemented by the association of organic farmers "Bio Austria" and included activities for the exchange of information and experience between scientific institutions and interested farmers. The practical part of the project was implemented by 7 farmers, united in the cooperative, and 6 local scientific institutions. $70 \%$ of funding was provided by donors from the $\mathrm{EU}$ and the Austrian Government, 30\% was paid by farmers and scientists provided free services (Fertl, 2015).

As a result of the project that lasted 1 year, about 120 varieties of cold-resistant organic salads were selected for farmers, individual crop rotation procedures were developed, as well as marketing activities were taken to promote salad selling. A year later, farmers noticed the growth of sales volumes to local consumers, chicory and radish were the most profitable ones. Also, all farmers noted the importance and effectiveness of cooperative promoting and tasting events.

It was noted that:

- 1 year is an insufficient period of time to achieve significant success for all members of a small organic cooperative; it takes at least 2 years;

- after the project is completed, resources are needed to support the obtained results and further development of farms, in particular, for information campaigns and marketing activities (Fertl, 2015).

The practice of running the organic dairy cooperative in Europe is also interesting for Ukrainian farmers. Irish producers of organic milk faced the problem of the non-compliance of the high cost of organic milk with fixed purchase prices and the lack of European sales quotas. In addition, in recent years it has become difficult for single farmers to compete with big agrarian companies. Therefore, having rallied, the farmers decided to try to increase purchasing prices for products and find ways to enter the European market (Westbrook, 2015).

After several meetings, 10 organic farmers founded the Little Milk Company. In addition, they decided to cooperate with marketers to promote cooperative products, which have never been done by any of those farmers.
Cooperation helped to form the system of year-round production of organic milk by keeping different species and setting the graphs of kettle birth. Farmers agreed with various local milk processors to make cheese under cooperative and personal brands, which allowed forming export parties of assorted cheeses. Thus, the cooperative was able to enrich the product range, to earn additional income from exports and to protect their farms from market price fluctuations. The creation of the cooperative and all its initial activities was financed by the farmers and by the rural development fund. After the first big parties were launched, investments from local businesses began to emerge.

As a result, farmers appreciated the value of active cooperative actions, which allowed increasing profitability, and found that cooperation is an effective way of competition for small producers of organic milk. Important results of this project are:

- understanding the value of financial literacy training for all farmers;

- gaining experience of effective competition with large producers of organic milk;

- understanding the role of cooperation in export operations;

- understanding the importance of collaboration with professional technologists and marketers, despite the high cost of their services (Westbrook, 2015).

The practice of organic cooperatives in the EU demonstrates the proactive stance of their participants; in particular, it reveals the important role of scientists and marketers in the successful implementation of development projects, which is important to understand for Ukrainian organic cooperative farmers.

\section{Development of organic farmers' cooperatives in Ukraine}

The organic agricultural market of Ukraine has gained significant growth rates and in 2017 reached a volume of 21 million euros. Since 2013, this indicator has increased by $110 \%$ (Trofimtseva, Prokopchuk, 2018). Information on the volume of the national market of organic products, the number of its producers and certified organic agricultural land in Ukraine in 20132017 can be found in Table 4 .

Table 4

Ukraine's organic agricultural land, number of producers, and market of organic products in 2013-2017

\begin{tabular}{|c|c|c|c|c|}
\hline \multirow{2}{*}{ Indicator } & \multicolumn{3}{|c|}{ Year } & $\begin{array}{c}3 \text { yrs growth, } \\
(\%)\end{array}$ \\
\cline { 2 - 5 } & 2013 & 2015 & 2017 & $-2,9$ \\
\hline $\begin{array}{c}\text { Agricultural land, } \\
\text { thousand ha }\end{array}$ & 393,4 & 400,7 & 382 & +86 \\
\hline Producers & 158 & 182 & 294 & +110 \\
\hline Market, billion Euro & 10 & 15 & 21 & \\
\hline
\end{tabular}

Source: (Amelina, 2014; Trofimtseva, Prokopchuk, 2018) 
The number of Ukrainian farmers who paid attention to the production of organic products for the study period increased by $86 \%$. And the number of certified organic land in Ukraine in 2017 decreased in comparison with both 2013 and 2015. This is explained by the complications of the political crisis in Ukraine, which began at the end of 2013 .

The largest share of agricultural land in Ukraine occupy organic crops - more than $48 \%$, slightly less - organic oil crops $-16.2 \%$, and legumes $-4.6 \%$. The smallest territory occupied by organic fruits and vegetables $-2 \%$ and $0.6 \%$ respectively.

Ukrainian organic agricultural products have been successfully exported to the USA, Canada, and the following EU countries: Germany, Austria, Poland, France, etc. Farmers export grain, oilseeds, and legumes as raw materials and jams, syrups and oils products of local Ukrainian brands (Trofimtseva, Prokopchuk, 2018).

Ukrainian farmers are already familiar with the practice of agricultural cooperatives, but this potential is not fully used. In 2016 Ukraine had 1026 agricultural service cooperatives (ASC) (Bezus, Burtak, 2018). But the given number of registered cooperatives does not reflect the actual number of organizations that are fully consistent with the principles of cooperation. According to the research data of the Dnipro State Agrarian and Economic University, there are 99 agricultural cooperatives in Ukraine that actually operate.

A significant number of associations registered as cooperatives are quasi-cooperatives, in particular, the following structures were found:

- forced farmers' association as a follower of the local collective farm;

- accidental farmers' association that has not fully understood the sense of cooperation;

- farmers' group gathered together to obtain state or international financing, etc.

That is, to establish the actual state of the cooperative movement in Ukraine, further research and their statistical and economic assessment are needed.

There are also "real" cooperatives that truly adhere to the principles of cooperation, where farmers successfully grow and sell grain, vegetables and fruits, produce milk and cheeses and even export their products abroad. These farmers develop their own business and support the social development of local communities using the money raised. In Ukraine, the experienced cooperation regions are Transcarpathia and Dnipropetrovsk region. A striking example of a successful cooperative of Transcarpathia is farmers' cooperative of the Nyzhnie Selyshche that is engaged in the production and export of milk and various cheeses. Another example of a successful cooperative in Dnipropetrovsk region is "Grain Cooperative". It has the only one cooperative elevator in Ukraine.

Having a positive experience in organic agribusiness and cooperatives, Ukrainian farmers are still on the way to the development of the organic cooperative movement.

Today there are plans to create two organic cooperatives in Ukraine:

- a servicing cooperative that is planned to create by the Agricultural Group "Arnika” in Vinnytsia region. It will occupy an area of 11 thousand hectares, where organic grains, vegetables and berries will be grown. Farmers estimate their possible additional income of $\$ 200-500$ per ha. But first, the land should be certified as organic;

- marketing (realization) cooperative will be created on the basis of the farm "VLT Flora" with an area of 50 hectares in the Kyiv region that grow organic raspberries, blueberries, and strawberries. The purpose of the creation of this cooperative is export of Ukrainian organic berries to Europe.

Currently, there is no official information on the progress of the implementation of these projects.

The actual state of the Ukrainian organic cooperative movement once again emphasizes the relevance of the current study and the recommendations on the development of organic cooperatives, extrapolating the experience of the USA and the EU.

\section{Marketing cooperatives in organic agribusiness}

The experience of successful cooperatives of the US and the EU points to the important role of marketing in cooperative organic agribusiness. Actual problems of small organic agribusiness are the lack of financial, credit, and resource support. Issues of products' certification and standardization, the search for effective selling channels remain important. Small agricultural producers are not able to overcome these challenges on their own. The real and urgent solution of these issues is the cooperation of farmers; it is very important in the current competition with agrarian holdings in the Ukrainian villages (Borschevskii, Magas, 2014).

A special type of cooperation is marketing cooperation that:

- helps to increase the demand for cooperative products;

- helps to improve the positioning of products, increase its competitiveness;

- provides an opportunity for the effective control of marketing channels, promotion of goods (Zinovchuk, 1996).

Cooperatives with the best marketing policy can prevent losses from negative price fluctuations or lack of active buyers in the market; providing services that farmers are not able to get otherwise and involve elements of innovative technologies to keep pace with the progress.

Marketing cooperatives can be classified according to their complexity and the number of functions: 
- local (small) marketing cooperatives that combine only individual farmers or family farms within a single territorial community and produce one or two types of products;

- state (large) marketing cooperatives that unite individual farmers, family farms, and service cooperatives specializing in various types of agricultural products; - international marketing cooperatives that combine individual farmers, family farms, and service cooperatives that have a mono- or mega-specialization and promote access of farm products to international markets.

The phenomenon of marketing cooperatives is widespread in the United States: almost every state has such cooperative. The professional organization, which includes Organic Valley, also has such a cooperative. In organic cooperatives of the EU, the marketing function is mainly performed by hired marketers.

In Ukraine so far there is no trend of creating the marketing cooperatives in traditional or organic agribusiness. Marketing functions are carried out mainly by the cooperative's manager, but this position exists not in every cooperative. Farmers can't compete with powerful agrarian holdings because they don't do professional market research. The benefits of marketing cooperative will help agricultural producers of organic products in Ukraine to reduce risks significantly and to avoid additional costs in the value chain of production and sales (Budnik, 2017).

\section{Conclusions}

Exploring the international experience of organic farmers' cooperatives, one can conclude that the path to success in this kind of agribusiness is not easy. There are a lot of risks, in particular:

- the risk of dissatisfaction with the expectations of all members of the cooperative;

- risk of non-optimal calculation of project implementation time;

- the risk of failure to compete with large agricultural producers;

- the risk of ruining the technology of organic growing and processing products in crisis periods and so on.

According to the experience of organic farmers' cooperatives of the US and the EU to minimize these risks and to promote the business Ukrainian farmers should:

- stay loyal to the idea of production without adding chemicals, despite market pressure and other circumstances;
- use simple practices and ingredients;

- enable farm animals to be just animals: all processes must be as natural as possible;

- don't be tempted with the idea of expansion to industrial scale;

- elect only the local successful farmer as the head of the cooperative;

- invite in cooperative only the true ideologues of organic grain production;

- employ a manager and a marketer that will promote products and distribute information about the cooperative;

- conduct trainings for updating knowledge about new organic technologies in grain production;

- understand that it takes a lot of time to reach agreements with all project participants, not just with the majority;

- understand that cooperative board must openly meet all the ideas and discuss them in detail;

- plan the project taking into account future modernization and attraction of innovations;

- take into account that 1 year is an insufficient period of time to achieve significant success for all members of a small organic cooperative, it takes at least 2 years;

- know that after the project is completed, resources are needed to support the obtained results and further development of farms, in particular, for information campaigns and marketing activities;

- consider the possibility of producing unique national products;

- understand the value of financial literacy training for all farmers;

- gain experience of effective competition with large producers of organic milk;

- understand the role of cooperation in export operations;

- understand the importance of collaboration with professional technologists and marketers, despite the high cost of their services.

The presented recommendations provide an opportunity to understand the ways of developing the organic farmers' cooperative, help to avoid risks optimally and support organic farmers' cooperative movement in Ukraine.

Further research will be directed to the collection of primary data on Ukrainian agrarian cooperatives and to various measures to support the cooperative movement in Ukraine.

\section{References:}

Amelina Y. (2014) Model perehodu na organichne virobnitstvo ovochiv vidkritogo gruntu. [The model transferring to organic vegetable production in open ground] Business inform, 5: 183-188. [In Ukrainian].

Bezus R., \& Burtak S. (2018) Chomu v Ukraini pomiraut kooperativi? [Why coops die in Ukraine?] kurkul.com. Retrieved from: https://kurkul.com/spetsproekty/248-chomu-v-ukrayini-pomirayut-kooperativi [In Ukrainian].

Borshchevskii V., \& Magas V. (2014) Silskogospodarska kooperatsia: rinkovi mehanizmi rozvitku [Agricultural cooperation: mechanisms of market development] Economics of AIC, No. 10: 3-5, [In Ukrainian]. 
Budnik O. (2017) Rozvitok kooperativnogo marketingu v Ukraini ta sviti [The development of cooperative marketing in Ukraine and worldwide] Agricultural and Resource Economics: International Scientific, Vol. 3, No. 1: 49-50 [In Ukrainian].

Coop Directory Service Listing (2017) coopdirectory.org. Retrieved from: http://coopdirectory.org/directory.htm Deep Root (2018) deeprootorganic.coop Retrieved from: http://www.deeprootorganic.coop/deeproot/co-op-faq/ Erinyak F. (2013) Ukrainian agribusiness is a good school, after which you can work anywhere and not to be scared. Latifundist.com. Retrieved from: http://latifundist.com/interview/48-floran-erinyak-ukrainskij-agrobizneshoroshayashkola-posle-kotoroj-rabotat-nigde-ne-strashno

European commission (2013). The EU's rural development policy 2014-2020. Agriculture and rural development. Retrieved from: https://ec.europa.eu/agriculture/rural-development-2014-2020_en

Fertl. T. (2015) Winter Harvest: Supporting the development of organic winter growing. Organic cooperative approaches to rural development. IFOAM EU Group: 10-12.

Hadfield M. (2017) USA's top 100 co-operatives of the year named by National Cooperative Bank. Thenews.coop. Retrieved from: https://www.thenews.coop/122959/sector/usas-top-100-co-operatives-year-named-nationalcooperative-bank/

Haumann B. (2016) U.S. organic industry continues to grow. FIBL \& IFOAM - Organics international (2016): The world of organic agriculture. Frick and Bonn: 258-264.

Haumann B. (2017) Organic continues to set records in the United States. The world of organic agriculture. Statistics and emerging trends. FIBL \& IFOAM - Organics international (2017). Frick and Bonn: 258-264.

Haumann B. (2018) U.S. organic sales set new records. FIBL \& IFOAM. Organics international (2018): The world of organic agriculture. Frick and Bonn: 284-289.

Lernoud J., \& Willer H. (2016) Current statistic on organic agriculture worldwide: area, operators, markets, and selected crops. FIBL \& IFOAM - Organics international (2016): The world of organic agriculture. Frick and Bonn: 34-114.

Lernoud J., \& Willer H. (2017) Current statistic on organic agriculture worldwide: area, operators, and market. The world of organic agriculture. Statistics and emerging trends. FIBL \& IFOAM - Organics international (2017). Frick and Bonn: 36-78.

Lernoud J., \& Willer H. (2018) Current statistic on organic agriculture worldwide: area, operators, and market. FIBL \& IFOAM. Organics international (2018): The world of organic agriculture. Frick and Bonn: 32-122.

Leriox J. (2015) Silo Bio Quest: A cooperative solution to ensure the quality of organic grain. Organic cooperative approaches to rural development. IFOAM EU Group: 14-16.

Organic agriculture could represent 15\% of the market in 2022 (2017). Lacooperationagricole.coop Retrieved from: https://www.lacooperationagricole.coop/agriculture-biologique/lagriculture-bio-pourrait-representer-15-dessurfaces-en-2022

Research on the Economic Impact of Cooperatives (2017) The University of Wisconsin Center for Cooperatives. www.uwcc.wisc.edu. Retrieved from: http://reic.uwcc.wisc.edu/summary/

The official website of Organic Valley Coop (2018) organicvalley.coop. Retrieved from: http://www.organicvalley.coop.

Trofimtseva O. \& Prokopchuk N. (2018) Organics in Ukraine. FIBL \& IFOAM. Organics international (2018): The world of organic agriculture. Frick and Bonn: 256-260.

USDA (2016) Top 100 Agriculture Cooperatives, 2016 and 2015, by Total Gross Business Revenue (Billion \$). USDA.gov. Retrieved from: https://www.rd.usda.gov/files/USDA2016NewTop100AgCoop.pdf

Voinea A. (2017) French agricultural co-operatives pledge to increase organic products. The Coop News, No. 11. Retrieved from: https://www.thenews.coop/120559/sector/french-agricultural-co-operatives-pledge-increaseorganic-products/

Westbrook G. (2015) The Little Milk Company: A group marketing initiative by organic dairy farmers. Organic cooperative approaches to rural development. IFOAM EU Group: 16-18.

What is coop? History (2010) The University of Wisconsin Center for Cooperatives. www.uwcc.wisc.edu. Retrieved from: http://www.uwcc.wisc.edu/whatisacoop/History/\#Post_World_War_II

Willer H., \& Schaak D. (2016) Organic farming and market development in Europe. FIBL \& IFOAM - Organics international (2016): The world of organic agriculture. Frick and Bonn: 199-220.

Willer H., Schaak D., \& Lernoud J. (2017) Organic farming and market development in Europe and the European Union. The world of organic agriculture. Statistics and emerging trends. FIBL \& IFOAM - Organics international (2017). Frick and Bonn: 207-245.

Willer H., Schaak D., \& Lernoud J. (2018) Organic farming and market development in Europe and the European Union. FIBL \& IFOAM. Organics international (2018): The world of organic agriculture. Frick and Bonn: 217-250.

Zinovchuk V. (1996) Cooperation idea in agriculture of the US and the Ukraine [Kooperativna ideia v silskomu gospodarstvi Ukraini I SShA], Kyiv: Logos [In Ukrainian]. 